\title{
Potensi Ekstrak Kangkung sebagai Biofungisida untuk Mengendalikan Penyakit Busuk Buah Fusarium pada Tomat
}

\author{
The Potency of Water Spinach (Ipomea aquatica) Extract as \\ Biofungicide for Controlling Fusarium Fruit Rot on Tomato
}

\author{
Bonny Poernomo Wahyu Soekarno ${ }^{1 *}$, Surono ${ }^{2}$, Eva Marhaenis ${ }^{1}$ \\ ${ }^{1}$ Institut Pertanian Bogor, Bogor 16680 \\ ${ }^{2}$ Balai Penelitian Tanah, Bogor 16114
}

\begin{abstract}
ABSTRAK
Salah satu patogen penting pada tanaman tomat ialah cendawan Fusarium sp. penyebab penyakit layu dan busuk buah. Penelitian ini bertujuan menguji potensi kangkung (Ipomea aquatic) sebagai biofungisida untuk menghambat pertumbuhan dan perkembangan busuk buah tomat yang disebabkan oleh Fusarium sp. Kemampuan penghambatan ekstrak batang kangkung terhadap pertumbuhan Fusarium sp. berkisar dari 3.40\% sampai $8.67 \%$, sedangkan ekstrak daun kangkung bisa mencapai $3.40 \%$ sampai $45.55 \%$. Uji induksi resistensi menunjukkan perlakuan in vitro ekstrak daun kangkung 20\% dapat memperpanjang waktu inkubasi busuk buah Fusarium dibandingkan dengan kontrol positif dan negatif. Ekstrak daun kangkung 20\% berpotensi sebagai biofungisida.
\end{abstract}

Kata kunci: biofungisida, Fusarium sp., Ipomea aquatica

\begin{abstract}
One of the important pathogens on tomato is Fusarium sp. causing wilt and fruit rot. This study aims to investigate the potency of water spinach (Ipomea aquatica) as a biofungicide for inhibiting growth and development of tomato fruit rot caused by Fusarium sp. This study showed inhibiting ability of I. aquatica stem extract to Fusarium sp. growth ranges from $3.40 \%$ to $8.67 \%$, while inhibiting ability of leaves extract can reach $3.40 \%$ to $45.55 \%$. Resistance induction test showed that in vitro treatment of I. aquatica leaves extract $20 \%$ can lengthen incubation time of Fusarium fruit rot compared to positive and negative control. Leaves extract of I. aquatica $20 \%$ is potential as biofungicide.
\end{abstract}

Key words: biofungicide, Fusarium sp., Ipomea aquatica

\section{PENDAHULUAN}

Cendawan Fusarium sp. merupakan salah satu patogen penting pada tanaman tomat penyebab penyakit layu dan busuk buah. Aplikasi biopestisida menggunakan ekstrak tanaman yang memiliki daya hambat terhadap patogen yang menyerang produk buah dan sayuran sudah dilaporkan (Shivpuri et al. 1997; Udo et al. 2001; Okigbo dan Nmeka
Kangkung (Ipomea aquatica) memiliki sifat antitoksik dan penenang, hal tersebut menjadi pertimbangan bahwa kangkung bisa digunakan sebagai biofungisida. Tanaman kangkung merupakan tanaman yang mempunyai kelebihan dalam tingkat kerusakan akibat serangan penyakit yang sangat rendah sehingga diindikasikan kangkung memiliki sistem pertahanan yang spesifik atau dalam tanaman ini mengandung senyawa antitoksik. 2005).

*Alamat penulis korespondensi: Departemen Proteksi Tanaman, Fakultas Pertanian, Institut Pertanian Bogor, Kampus Darmaga, Jalan Kamper, Bogor 16680

Tel: 0251-8629364, Faks: 0251-8629362,Surel: bonny_soekarno@yahoo.com 
Penelitian bertujuan menguji potensi ekstrak kangkung sebagai biofungisida untuk menghambat pertumbuhan dan perkembangan penyakit busuk buah tomat yang disebabkan oleh cendawan Fusarium sp.

\section{BAHAN DAN METODE}

\section{Isolat Fusarium sp.}

Isolasi Fusarium sp. dilakukan dari buah tomat di pasar yang menunjukkan gejala busuk Fusarium dengan metode tanam langsung. Potongan jaringan $5 \mathrm{~mm}$ x $5 \mathrm{~mm}$ direndam di dalam $\mathrm{NaOCl} 1 \%$ selama 1 menit, lalu dibilas menggunakan air steril dan dikeringanginkan pada kertas saring steril. Potongan jaringan buah tomat tersebut selanjutnya diletakkan pada cawan berisi medium potato dextrose agar (PDA) dan diinkubasi pada suhu ruang selama 48 jam. Koloni cendawan yang tumbuh diidentifikasi. Hasil isolat yang diidentifikasi sebagai Fusarium sp. dimurnikan dan digunakan dalam uji lanjut.

\section{Ekstrak Kangkung}

Kangkung yang berasal dari petani dipisahkan menjadi bagian batang dan daun. Masing-masing bagian diekstrak secara terpisah. Batang dan daun kangkung dibersihkan dan dipotong-potong secara terpisah, kemudian dihaluskan menggunakan mortar, ditambah air steril dengan perbandingan $200 \mathrm{~mL}$ untuk $80 \mathrm{~g}$ kangkung, dan disaring secara bertahap. Filter vakum dengan saringan kasa digunakan untuk memisahkan ampas kangkung, selanjutnya disaring kembali menggunakan kertas Whatman $0.4 \mu \mathrm{m}$ juga dengan filter vakum sehingga diperoleh ekstrak batang kangkung dan ekstrak daun kangkung.

\section{Uji Daya Hambat}

Uji daya hambat ekstrak kangkung terhadap pertumbuhan koloni Fusarium sp. dilakukan pada medium PDA. Masingmasing ekstrak dicampur dengan PDA yang masih cair sehingga terbentuk medium dengan ekstrak kangkung konsentrasi 2.5, 5.0, 10.0, dan 20.0\%; ekstrak batang kangkung diberi kode $\mathrm{B}$ dan daun kangkung diberi kode D.
Selanjutnya, isolat Fusarium sp. berdiameter $5 \mathrm{~mm}$ ditumbuhkan pada semua medium uji. Sebagai kontrol negatif, isolat Fusarium sp. ditumbuhkan pada medium PDA tanpa penambahan ekstrak kangkung sebagai kontrol negatif (KN), sedangkan untuk kontrol positif (KP) isolat Fusarium sp. ditumbuhkan pada medium PDA yang dicampur dengan fungisida propineb $70 \%$ dengan konsentrasi $0.2 \%(\mathrm{~b} / \mathrm{v})$. Setiap perlakuan uji in vitro ini diulang sebanyak 10 kali.

Hasil uji in vitro dengan konsentrasi ekstrak kangkung yang efektif menekan pertumbuhan koloni Fusarium sp. digunakan dalam uji in vivo. Uji ini terdiri atas uji kuratif dan uji preventif. Uji kuratif (KR) dilakukan untuk mengetahui kemampuan ekstrak kangkung menekan kejadian penyakit busuk buah tomat setelah terjadi serangan Fusarium sp. Perlakuan secara kuratif dilakukan setelah muncul gejala pertama busuk buah Fusarium dan pengamatan dilakukan selama 7 hari setelah perlakuan (HSP).

Buah tomat diseka dengan alkohol 70\%, dikeringanginkan, lalu diinokulasi dengan metode penetesan suspensi konidium Fusarium sp. $10^{6}$ dan diinkubasi sampai muncul gejala busuk buah Fusarium untuk pertama kali. Setelah muncul gejala, buah tomat direndam dalam suspensi ekstrak kangkung selama 10 menit, dikeringanginkan, diletakkan di atas nampan, dan selanjutnya diinkubasi selama 7 hari. Sebagai kontrol negatif, buah tomat diinkubasi tanpa direndam dalam ekstrak kangkung. Untuk kontrol positif, buah tomat direndam dalam suspensi fungisida berbahan aktif propineb $70 \%$ dengan konsentrasi $0.2 \%(\mathrm{~b} / \mathrm{v})$. Perlakuan diulang sebanyak 3 kali dan setiap ulangan terdiri atas 5 buah tomat. Perkembanagn penyakit busuk Fusarium pada buah tomat diamati setiap hari.

Uji preventif dilakukan untuk mengetahui potensi ekstrak kangkung untuk mencegah infeksi penyakit busuk Fusarium pada buah tomat. Perlakuan ekstrak kangkung dilakukan sebelum muncul gejala busuk buah Fusarium. Buah tomat disterilkan dengan alkohol $70 \%$ dan dikeringanginkan, kemudian direndam dalam suspensi ekstrak kangkung 20\% selama 10 menit, dan dikeringanginkan. 
Buah tomat disimpan pada suhu ruang dalam nampan selama 24 jam, kemudian diinokulasi dengan suspensi konidium Fusarium sp. $10^{6}$ menggunakan metode penyemprotan, dan selanjutnya diinkubasi selama 7 hari. Sebagai kontrol negatif, buah tomat diinkubasi tanpa perlakuan perendaman dalam ekstrak kangkung; sedangkan untuk kontrol positif, buah tomat direndam dalam suspensi fungisida berbahan aktif propineb $70 \%$ dengan konsentrasi $0.2 \%(\mathrm{~b} / \mathrm{v})$ dan selanjutnya disemprot suspensi konidium Fusarium sp. $10^{6}$. Gejala penyakit yang muncul diamati setiap hari. Perlakuan diulang sebanyak 3 kali dan setiap ulangan terdiri atas 5 buah tomat.

Uji preventif dibedakan berdasarkan pengaruh induksi resisten (PIR) dan pengaruh residu (PR). Buah tomat pada uji berdasarkan PIR, setelah direndam dalam ekstrak kangkung dan diinkubasi selama 1 hari, dicuci menggunakan air steril, kemudian diinokulasi dengan konidium cendawan. Pada uji berdasarkan PR, setelah perlakuan ekstrak kangkung dan inkubasi selama 1 hari, buah tomat tidak dicuci dengan air steril, melainkan langsung diinokulasi dengan konidium cendawan.

\section{Pengamatan}

Peubah yang diamati meliputi daya hambat ekstrak kangkung terhadap Fusarium sp., masa inkubasi Fusarium sp. sampai menunjukkan gejala pertama pada buah tomat, kejadian penyakit, dan intensitas penyakit pada buah tomat.

Daya hambat ekstrak kangkung terhadap pertumbuhan Fusarium sp. in vitro pada 7 HSP dihitung menggunakan rumus:

$$
\text { Daya hambat }=\frac{\varnothing \mathrm{K} 1-\varnothing \mathrm{P} 1}{\varnothing \mathrm{K} 1} \times 100 \% \text {, dengan }
$$

ØK1, diameter koloni kontrol (cm);

ØР1, diameter koloni perlakuan $(\mathrm{cm})$.

Masa inkubasi merupakan waktu yang diperlukan Fusarium sp. untuk menimbulkan gejala pertama pada buah tomat setelah diinokulasi.

Kejadian penyakit dihitung berdasarkan pada jumlah buah yang diserang Fusarium sp. terhadap populasi buah yang diamati.
Kejadian penyakit dihitung dengan rumus:

$$
\mathrm{KP}=\frac{\mathrm{n}}{\mathrm{N}} \times 100 \% \text {, dengan }
$$

KP, kejadian penyakit; $n$, jumlah buah tomat yang menunjukkan gejala busuk buah; $\mathrm{N}$, jumlah buah tomat yang diamati dalam setiap perlakuan.

Intensitas penyakit atau disebut juga sebagai tingkat perkembangan keparahan penyakit pada inang dihitung dengan rumus:

$$
\mathrm{IP}=\frac{\sum \text { ni.vi }}{\mathrm{N} . \mathrm{V}} \times 100 \%, \text { dengan }
$$

ni, jumlah tanaman dengan skor ke-I;

vi, nilai skor penyakit;

$\mathrm{N}$, jumlah tanaman yang diamati;

V, skor tertinggi.

Skor gejala busuk buah yang disebabkan oleh infeksi Fusarium sp. dihitung dengan metode Swart (1999) yang telah dimodifikasi sebagai berikut.

0 , tidak ada busuk;

$1,0 \%<$ persentase busuk $\leq 10 \%$;

$2,10 \%<$ persentase busuk $\leq 20 \%$;

$3,20 \%<$ persentase busuk $\leq 40 \%$,

$4,40 \%<$ persentase busuk $\leq 60 \%$;

5 , persentase busuk $>60 \%$.

Percobaan ini disusun dalam rancangan acak lengkap. Pada uji daya hambat ekstrak kangkung terhadap Fusarium sp. in vitro dengan 10 perlakuan yang terdiri atas 4 perlakuan ekstrak batang kangkung, 4 perlakuan ekstrak daun kangkung, kontrol negatif tanpa perlakuan, dan kontrol positif dengan fungisida propineb $70 \mathrm{WP}$ masing-masing 10 ulangan. Pada uji in vivo terdapat 5 uji yang terdiri atas uji kuratif, uji preventif PRI induksi resistensi, uji preventif PR, kontrol negatif tanpa perlakuan, dan kontrol positif dengan fungisida propineb 70 WP masingmasing diulang 3 kali.

\section{HASIL}

\section{Pengaruh Aplikasi Ekstrak Kangkung Secara in Vitro}

Daya hambat ekstrak batang kangkung terhadap pertumbuhan Fusarium sp. secara in vitro berkisar 3.40-8.67\%, sedangkan 
daya hambat ekstrak daun berkisar 13.74$45.55 \%$ (Gambar 1). Hasil percobaan in vitro pada medium tumbuh menunjukkan ekstrak daun kangkung lebih efektif menghambat pertumbuhan koloni Fusarium sp. daripada ekstrak batang kangkung. Perlakuan ekstrak daun kangkung pada konsentrasi 20\% (D4) menunjukkan daya hambat yang paling tinggi, yaitu sebesar $45.5 \%$ terhadap pertumbuhan koloni Fusarium sp. dibandingkan dengan perlakuan ekstrak lain dan kontrol negatif.

Potensi ekstrak daun kangkung sebagai biofungisida pada percobaan ini diukur dari daya hambat ekstrak daun kangkung terhadap pertumbuhan koloni Fusarium sp. Diameter koloni Fusarium sp. pada medium yang diberi perlakuan ekstrak daun kangkung $20 \%$, yaitu $4.52 \mathrm{~cm}$, berbeda nyata dengan kontrol negatif (KN) yang mencapai $8.12 \mathrm{~cm}$, sedangkan dengan kontrol positif (KP) tidak berbeda nyata. Oleh karena itu, perlakuan ekstrak daun kangkung 20\% digunakan dalam uji in vivo.

\section{Pengaruh Aplikasi Ekstrak Daun Kangkung terhadap Masa Inkubasi}

Berdasarkan pada hasil uji in vitro, ekstrak daun kangkung 20\% selanjutnya digunakan pada percobaan in vivo. Pada PIR perlakuan ekstrak daun kangkung 20\% mampu memperpanjang masa inkubasi penyakit busuk buah Fusarium dibandingkan dengan kontrol positif dan negatif, meskipun di antara ketiganya tidak berbeda nyata (Tabel 1).
Meskipun tidak berbeda nyata, masa inkubasi pada perlakuan ekstrak daun kangkung 20\% lebih lama dibandingkan dengan perlakuan kontrol positif sehingga ekstrak daun kangkung $20 \%$ berpotensi menggantikan fungisida yang digunakan secara in vitro.

Pada pengujian kuratif dan preventif perlakuan ekstrak daun kangkung 20\% tidak berpengaruh nyata terhadap masa inkubasi penyakit busuk buah Fusarium pada buah tomat dibandingkan dengan kontrol positif maupun kontrol negatif. Meskipun demikian, waktu inkubasi perlakuan ekstrak kangkung $20 \%$ pada pengujian kuratiflebih lama satu hari dibandingkan dengan penggunaan fungisida berbahan aktif propineb $70 \%$ konsentrasi $0.2 \%$ sebagai kontrol positif, demikian juga dengan uji preventif (Tabel 1).

Tabel 1 Pengaruh aplikasi ekstrak daun kangkung 20\% terhadap masa inkubasi Fusarium sp. dengan uji kuratif dan preventif

\begin{tabular}{lccc}
\hline \multirow{2}{*}{ Perlakuan } & \multicolumn{3}{c}{ Masa inkubasi (hari)* } \\
\cline { 2 - 4 } & KR & PIR & PR \\
\hline D4 & $5.33 \mathrm{a}$ & $6.00 \mathrm{a}$ & $5.33 \mathrm{a}$ \\
KN & $2.50 \mathrm{a}$ & $4.50 \mathrm{a}$ & $2.50 \mathrm{a}$ \\
KP & $5.00 \mathrm{a}$ & $5.50 \mathrm{a}$ & $6.00 \mathrm{a}$ \\
\hline
\end{tabular}

*Angka yang diikuti huruf berbeda menunjukkan hasil yang berbeda nyata (uji selang berganda Duncan $\alpha=$ 0.05). KR, kuratif; PIR, preventif pengaruh induksi resistensi; PR, preventif pengaruh residu; D4, ekstrak kangkung pada konsentrasi $20 \%$; KN, kontrol negatif; $\mathrm{KP}$, kontrol positif

b

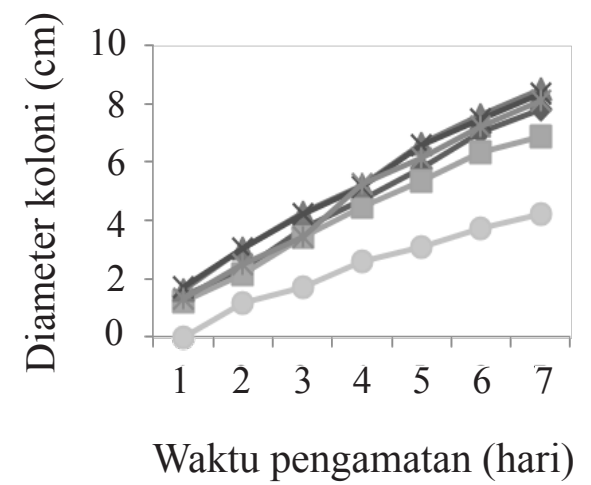

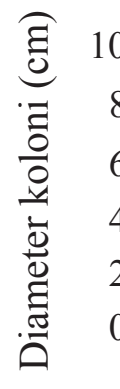

$\begin{array}{lllllll}1 & 2 & 3 & 4 & 5 & 6 & 7\end{array}$

Waktu pengamatan (hari)

Gambar 1 Pertumbuhan koloni Fusarium sp. pada medium PDA dengan berbagai konsentrasi: a, ekstrak batang dan $\mathrm{b}$, daun kangkung. B1, ekstrak batang 2.5\%; B2, ekstrak batang 5.0\%; B3, ekstrak batang 10.0\%; B4, ekstrak batang 20.0\%; D1, ekstrak daun 2.5\%; D2, ekstrak daun 5.0\%; D3, ekstrak daun 10.0\%; D4, ekstrak daun 20\%; KN, kontrol negatif; KP, kontrol positif. 


\section{Pengaruh Aplikasi Ekstrak Daun Kangkung terhadap Kejadian dan Intensitas Penyakit}

Kejadian penyakit pada kuratif tidak berbeda nyata dengan kontrol negatif, yaitu sebesar 60\%, sedangkan pada pengujian preventif pengaruh induksi resisten kejadian penyakit yang timbul sebesar $30 \%$. Kejadian penyakit pada perlakuan induksi resisten tidak berbeda nyata dengan pengaruh residu. Kejadian penyakit pada perlakuan preventif pengaruh residu berbeda nyata dengan perlakuan kontrol negatif dan tidak berbeda nyata dengan kontrol positif, yaitu penggunaan fungsida (Tabel 2). Perkembangan penyakit busuk Fusarium dapat ditekan karena pengaruh induksi resistensi maupun pengaruh residu.

Perlakuan preventif dan kuratif dengan pengaruh residu menunjukkan intensitas penyakit yang rendah dibandingkan dengan kontrol negatif (Tabel 2).

Ekstrak daun kangkung 20\% mempunyai potensi sebagai biofungsida untuk menekan pertumbuhan koloni Fusarium sp. dan menekan secara nyata kejadian penyakit dan intensitas penyakit busuk buah yang disebabkan Fusarium sp. pada buah tomat.

\section{PEMBAHASAN}

Busuk buah Fusarium merupakan penyakit paling umum yang dijumpai pada buah tomat yang disimpan di tempat penyimpanan atau gudang terutama pada saat musim panen melimpah. Penyakit ini menyerang terutama jika sistem penyimpanan tidak baik sehingga mendorong pertumbuhan dan penyebaran
Fusarium dengan mudah. Keberadaan cendawan Fusarium pada buah tomat bisa menyebabkan kerusakan dan kerugian secara ekonomi yang besar. Kehilangan ini berkisar 4-8\% untuk negara yang memiliki fasilitas pendinginan (refrigeration) yang bagus dan sampai $50 \%$ untuk negara dengan fasilitas pendinginan yang minimal (Eckert dan Ogawa 1985). Di samping itu, busuk buah tomat akibat serangan cendawan patogen ini bisa menyebabkan permasalahan kesehatan pada manusia karena produksi mikotosin yang dihasilkan oleh cendawan patogen tersebut (Walker 1971).

Sejumlah spesies Fusarium yang berbeda berasosiasi terhadap munculnya busuk buah pada buah tomat. Thakur dan Yadav (1971) melaporkan Fusarium nivale sebagai penyebab buah busuk tersebut, sedangkan Banyal et al. (2008) melaporkan penyebab busuk buah tomat Fusarium ialah Fusarium oxysporum, F. pallidoroseum, dan F. accumunatum.

Maraknya aplikasi pertanian organik berdampak pada pemanfaatan pupuk dan pestisida yang menggunakan bahan dasar tanaman maupun mikrob. Efek penggunaan pestisida kimia telah diketahui berpengaruh pada kondisi tanah, air, produk pertanian yang diberi perlakuan dan manusia pengguna pestisida tersebut, yang cenderung menimbulkan permasalahan. Pengunaan pestisida hayati sebagai pengendali penyakit dan hama yang ramah lingkungan akan dapat menekan pengunaan pestisida kimia yang selama ini telah digunakan secara besar-besaran, serta akan membantu pemulihan ekosistem pertanian dan menjaga

Tabel 2 Pengaruh aplikasi ekstrak daun kangkung 20\% terhadap kejadian dan intensitas penyakit busuk buah Fusarium dengan uji kuratif dan preventif

\begin{tabular}{lcc}
\hline Perlakuan & Kejadian penyakit $(\%)^{*}$ & Intensitas penyakit $(\%)^{*}$ \\
\hline KR & $40.0 \mathrm{ab}$ & $20.0 \mathrm{c}$ \\
PIR & $30.0 \mathrm{abc}$ & $24.0 \mathrm{~b}$ \\
PR & $20.0 \mathrm{bc}$ & $20.0 \mathrm{c}$ \\
KN & $50.0 \mathrm{a}$ & $56.0 \mathrm{a}$ \\
KP & $16.67 \mathrm{c}$ & $16.0 \mathrm{~d}$ \\
\hline
\end{tabular}

*Angka yang diikuti huruf berbeda menunjukkan hasil yang berbeda nyata (uji selang berganda Duncan $\alpha=0.05$ ) KR, kuratif; PIR, preventif pengaruh induksi resisten; PR, preventif pengaruh residu; KN, kontrol negatif; KP, kontrol positif 
keseimbangan lingkungan (Soytong et al. 1999). Salah satu tanaman berpotensi untuk digunakan sebagai bahan untuk pengendali penyakit tanaman ialah tanaman kangkung air.

Daun dan bunga kangkung mengandung antioksidan serta memiliki kandungan alkohol larut terekstrak sebesar 21.92\% (Manvar 2011). Pengaruh residu ini menimbulkan efek alelopati yang menghambat pertumbuhan cendawan atau mikrob yang lain. Efek alelopati adalah kemampuan tumbuhan untuk menghasilkan senyawa kimia yang dapat menghambat pertumbuhan mikrob (Balandrin et al. 1985).

Tanaman mempunyai mekanisme pertahanan terhadap serangan infeksi patogen dengan menghasilkan senyawa seperti peptida, protein, flavanoid, dan senyawa organik lainnya (Muthukumaran et al. 2011). Daun kangkung mengandung flavanoid sebesar $37.6 \%$ yang merupakan senyawa fenolat terhidroksilasi dan senyawa tersebut disintesis tanaman sebagai respons terhadap infeksi mikrob patogen (Yadav dan Argawala 2011). Berdasarkan hasil penelitian tersebut, ekstrak kangkung mempunyai potensi sebagai anticendawan untuk menekan pertumbuhan Fusarium sp. penyebab penyakit busuk buah tomat. Bhakta et al. (2009) melaporkan bahwa senyawa flavonoid dapat menghambat bakteri Staphyllococcus aureus, Pseudomonas aeruginosa, dan Escherichia coli.

Hasil penelitian yang telah dilakukan menunjukkan ekstrak kangkung mampu menekan intensitas penyakit busuk buah tomat sebesar 64\%. Ekstrak daun kangkung $20 \%$ dapat dimanfaatkan sebagai biofungisida untuk mengendalikan penyakit busuk buah Fusarium pada buah tomat secara ramah lingkungan. Dengan demikian, penggunaan ekstrak daun kangkung dapat menekan penyebaran dan serangan Fusarium pada buat tomat di tempat penyimpanan atau gudang.

\section{DAFTAR PUSTAKA}

Balandrin NF, Klocke JA, Wurtele ES, Bollinger WH. 1985. Natural plant chemicals: source of industrial and medicinal mate- rials. Science. 228(4704):1154-1160. doi: 10.1126/science.3890182.

Banyal DK, Mankotia V, Sugha SK. 2008. Integrated management of tomato collar rot caused by Sclerotium rolfsii. J Mycol Plant Pathol. 38(2):165-167.

Bhakta JN, Majumdar P, Munekage Y. 2009. Antimicrobial efficacies of methanol extract of Asteracantha longifolia, Ipomoea aquatica and Enhydra fluctuans against Escherichia coli, Pseudomonas aeruginosa, Staphylococcus aureus and Micrococcus luteus. Internet J Alternative Med. 7(2). doi: 10.5580/95a.

Eckert JW, Ogawa JM. 1985. The chemical control of postharvest diseases: Subtropical and tropical fruits. Ann Rev Phytopathol. 23:421-454. doi: 10.1146/annurev.py.23. 090185.002225.

Manvar, Mital N. 2011. Pharmacognostical investigations on Ipomoea aquatica Forsk. IJPSR. 2(11):2812-2815.

Muthukumaran P, Padmapriya P, Salomi $\mathrm{S}$, Umamaheshwari R, Kalaiarasan $\mathrm{P}$, Malarvizhi C. 2011. In vitro anti microbial activity of leaf powder. Asian J Pharm Res. 1(4):108-110.

Okigbo RN, Nmeka IA. 2005. Control of yam tuber rot with leaf extracts of Xylopia aethiopica and Zingiber officinale. Afr J Biotechnol. 4(8):804-807.

Shivpuri A, Sharma OP, Thamaria S. 1997. Fungitoxic properties of plant extracts against pathogenic fungi. J Mycol Plant Pathol. 27(1):29-31.

Soytong K, Jindawong N, Yang Q. 1999. Evaluation of Chaetomium for biological control of Fusarium wilt of tomato in PR China. Di dalam: Proceeding of the 5 th International Conference on Plant Protection in the Tropics; 1999 Mar 1518; Kuala Lumpur (MY): Malaysian Plant Protection Society. hlm 484-487.

Swart GM. 1999. Comparative study of Colletotrichum gloesporioides from avocado and mango [disertation]. Pretoria (ZA): University of Pretoria.

Thakur DP, Yadav YC. 1971. A new fruit rot of tomato. Ind Phytopathol. 24:583-585. 
Udo SE, Madunagu BE, Isemin CD. 2001. Yadav RNS,Agarwala M.2011. Phytochemical Inhibition of growth and sporulation of fungal pathogens on sweet potato and yam analysis of some medicinal plants. J Phytol. by garlic extract. Nig J Bot. 14:35-39.

Walker JC. 1971. Fusarium Wilt of Tomato. St. Paul (US): Am Phytopathol Soc. 